\title{
The Structure of Opportunity: Middle-Class Mobility in England, 1548-1689 ${ }^{1}$
}

\author{
Peter S. Bearman \\ University of North Carolina at Chapel Hill \\ Glenn Deane \\ State University of New York at Albany
}

\begin{abstract}
Models that allow the decomposition of mobility into its structural and exchange components are used to identify the structure, and consequences, of middle-class intergenerational mobility in preindustrial (1548-1689) Norwich, England. Dramatic shifts in the mobility opportunities of sons over time are seen to yield distinct political outcomes. Political stability is associated with almost universal upward mobility in the period from 1548 to 1589 , while from 1590 to 1639 structural processes leading to massive downward mobility are associated with increased radicalization and participation in the English civil war. From 1640 to 1689, strata persistence in an unstable political context prevailed.
\end{abstract}

\section{INTRODUCTION}

In this article we analyze the occupational mobility experiences of the urban middle class in Norwich, England, from 1548 to 1689. Our first goal, to identify the determinants of mobility across a substantively important historical context, is largely descriptive. Our second goal is interpretive and aims to link the collective mobility experiences of men to the demographic, economic, social, and political processes which occurred in England during the 16th and 17th centuries.

\footnotetext{
${ }^{1}$ We are grateful for the advice of Gerhard Arminger, Judith R. Blau, Kenneth A. Bollen, Jack A. Goldstone, Michael Hout, Richard Lachmann, Philip J. O'Connell, and the $A J S$ reviewers in the preparation of this article. This research was facilitated by grants from the Institute for Research in Social Science and from the Faculty Research Council both at the University of North Carolina. Both authors participated equally in the production of this paper. Direct all correspondence to Peter S. Bearman, Department of Sociology, University of North Carolina, Chapel Hill, North Carolina 27514.
}

() 1992 by The University of Chicago. All rights reserved. 0002-9602/93/9801-0002\$01.50 
Our approach makes use of an existing family of log-linear models that we use to analyze cross-classificatory tables. This allows for a unique partition of mobility dynamics as resulting either from structural or exchange mobility (Sobel, Hout, and Duncan 1985; Sobel 1988). The ability to distinguish between structural and exchange mobility is a critical component of most models of intergenerational occupational mobility in contemporary contexts (Featherman and Hauser 1978; Sobel et al. 1985). In this article, we show that distinguishing between structural and exchange components of a mobility regime is a basic prerequisite for understanding the social and political consequences of mobility in its historical context.

There are others who have seen the importance of mobility regimes as shapers of historical context (cf. Goldstone 1991; Stone 1965; Hexter 1963). Few have tried, however, to distingiush the unique political outcomes of patterns of mobility across regimes. For sons of landed elites, Goldstone (1991) identifies two mobility patterns-"expansion" and "turnover and displacement"-which are largely driven by population growth and contraction. He argues that expansion regimes co-opted newcomers and resulted in political stability, while displacement regimes generated elite competition and factionalism, and ultimately radicalized elements of the landed gentry. This is a provocative argument and one to which we are generally sympathetic. While the mobility patterns Goldstone identifies neglect patterned downward mobility and fail to distinguish between the structural and exchange components of a mobility regime - thereby conflating exogenous demographic effects with endogenous mobility effects - the period-specific structure of middle-class mobility that we identify corresponds roughly to his discussion of the patterns of elite mobility. We show that structurally driven downward mobility, in the period 1590-1639, led to the radicalization of sectors of the urban middle class, whereas the more "expansionary" period of 1548-89 was associated with political stability. Our models, supported by Goldstone's less quantifiable evidence, point toward the critical political role that intergenerational mobility plays in historical context. A central focus of this article is thus concerned with exploring the complicated interaction between mobility regimes and political action.

England from 1548 to 1689 provides a rich setting for our study. Consider just a few of the economic, social, and political developments that occurred: the price and population revolution (1548-1640), expansion of centralized markets for food and commodities (1548-1689), a rapid emergence of a permanent wage-labor force (Bowden 1967; Lachmann 1987), and spatial expansion of protoindustrial activity in the countryside (Kriedte, Medich, and Schlumbohm 1981). If the pace of economic change was rapid, so was the pace of political and cultural change. At the start of our period, in 1548, county elites thought of themselves as 
members of a county community. In 1640, local gentry conceived of themselves as members of a national political community and participated in a prolonged civil war that led to the execution of a reigning monarch (Bearman 1992). Likewise, in 1548, the politics of urban elites outside of London consisted of struggles for place and prominence within the local urban setting - and yet by 1640, urban provincial elites actively participated in the civil war and revolutionary government that followed (Allen 1951; Evans 1979). In 1548, English political society was localist, by 1640 , and certainly by 1689 , most of the politically active class worked within a framework of national politics. Cultural change was also dramatic. Radical religious beliefs - the various forms of Puritanismemerged during this period and motivated both new forms of political agency and new models for economic action (Walzer 1965; Weber 1958; Bearman 1992).

If we consider the crucial cultural, political, economic, and structural changes that occurred in English society from 1548 to 1640 - the industrialization of the countryside, the emergence of national food and commodity markets, the rise of large-scale urban manufacturing, the rise of Puritanism, and a radical civil war that permanently altered the structure of politics-we find an interesting constant. Common to all of these developments, two groups played a central role: the landed elite and the urban commercial middle class.

As a rule, historians have stressed the localist and narrow role played by the provincial urban middle class in these macro-level transformations (Everitt 1969; Evans 1979; Howell 1967; Clarke 1976). Likewise, historians have tended to see local urban social structure as largely insulated from macro-level, exogenous shifts in the economy (Evans 1979; Allen 1951). Both views fit poorly with a number of our findings. Rather than observing independence and isolation of the middle class, we show that the fortunes of the middle class were inextricably tied to larger exogenous processes and that the experience of downward and blocked mobility from 1590 to 1640 was associated with participation in the civil war of 1640. Below we focus on both the causes and consequences of the mobility regimes that we identify in our analyses.

The mobility experiences we analyze are limited to father-son pairs, of which the sons were enrolled as freemen in the city of Norwich. Throughout, our focus is on the men who controlled influence and assets beyond their own labor power and who, consequently, drove the provincial economy. These men were "work givers," purchasing the labor power of others, rather than "work takers," men who exchanged labor power for a wage. This focus on middle-class mobility sheds light on one level of social stratification within the urban social structure. Missing is the mass of men and women who worked in agricultural occupations, those who 
labored in the large urban manufactories, those who worked at home in protoindustrial rural cottage industries as weavers, spinners, and combers, and those on the top of the English preindustrial stratification system, the landed elite.

The models that we use are designed to partition structural and exchange mobility. This partition is of interest to us so that we can describe and compare structures of opportunity over time. Therefore, our analysis focuses on the structural dimensions of mobility regimes and ignores individual correlates of occupational mobility. While the models we employ have provided a stepping-stone for structural equation models of the individual determinants of mobility, net of structural constraint resulting from marginal heterogeneity (DiPrete 1990; Hout 1988; Landale and Guest 1990), our goal is necessarily different. Studies of 20th-century mobility typically include covariates of the status attainment process in addition to origin; the most important among these are education, ethnicity, and race (Featherman and Hauser 1978; Hout 1988). These covariates are not salient for preindustrial mobility in Norwich. We seek to interpret strata mobility within the political and economic context of that era and place.

Over the 140 years from 1548 to 1689 , mobility was driven by structural shifts in the distribution of vacancies, forcing sons through occupational strata characterized by strong, diffuse associations. By itself this is interesting, but this summary statement masks critical differences across each of the three periods analyzed: 1548-89, 1590-1639, and 1640-89. Much of our descriptive focus is thus on delineating periodspecific mobility patterns and comparing these patterns to the earlier mobility regimes. To anticipate our central results, we show that in period 1 , from 1548 to 1589 , Norwich urban middle-class men experienced sustained, structurally driven upward mobility. Across all but one stratum, sons occupied (on average) higher status jobs than their fathers. An expanding export economy driven largely by gains in the textile/woolen sector lay behind this long period of upward mobility. We argue that political stability is associated with the structurally driven upward mobility.

In period 2, from 1590 to 1639 , sons of fathers in the elite strata experienced massive downward mobility driven by structural processes, while sons of lower-status fathers experienced blocked aspirations as the result of there being too few elite vacancies. We argue that the radicalization of sons within the Norwich middle class, and their support for Parliament during the English civil war, follows two generations of structurally driven downward mobility. We show that those strata most likely to yield radical leaders in Norwich were those that evidenced the highest levels of blocked mobility during this period. 
From 1640 to 1689 , the mobility regime is best fit by a model of quasi independence, indicating strata inheritance and the independence of mobility across occupational strata. In the first period, structurally driven upward mobility was associated with political stability. In the second period, the antecedent effects of downward mobility were associated with the radicalization of sectors of the urban elite during the English civil war and interregnum. Here the absence of patterned mobility-almost $70 \%$ of all sons inherited their fathers' strata-suggests that local political events were relatively autonomous of the Norwich mobility regime. It follows that one must search for causes beyond the mobility experiences of men to account for the political changes that occurred at the end of our third period.

Over time, men's mobility was driven by structural change in the distribution of vacancies across the upper part of the classification strata. A different stratum in each period played the leading role and thus largely defined the opportunities available for sons in other strata. The fortunes of the merchant elite, distributive, skilled crafts, weaver, and allied cloth strata shifted radically over time, largely in response to exogenous macro-level developments that transformed the local setting. Opportunity was defined by structural shifts in the distribution of vacancies, which serve to drive men into occupational strata. Structural mobility results from macro-level impacts that cause declines in one stratum and increases in others. To understand structural mobility, we have to understand the operators - in the economy and in politics - that determine marginal heterogeneity. By far the most important operators driving the preindustrial mobility regime of England were national, namely the rise of the new draperies, the decline of local luxury markets stimulated by central London expansion, and demographic stagnation.

\section{DATA AND CONTEXT}

A major constraint governing research into the structure of preindustrial intergenerational mobility is the absence of data of sufficient quality. With the exception of the recent work by Guest, Landale, and McCann (1989) and Landale and Guest (1990) on the structure of occupational mobility at the turn of the 20th century in the United States, Katz's (1975) work on urban Canadian mobility, Thernstrom's (1964) models of late 19th-century mobility in America, and Sharlin's (1979) research on mobility of middle-class artisans in Frankfurt, much of the earlier research has suffered from marginal data and weak sample frames. ${ }^{2}$ These

\footnotetext{
${ }^{2}$ In addition to selectivity bias in the samples has been the unfortunate tendency in historical research to misclassify occupations and categories. Occupational misclassi-
} 
weaknesses have led to conflicting assessments of the structure of mobility before the Industrial Revolution, making even simple statements about the comparative openness of mobility regimes hazardous. Because intergenerational mobility data require that a sample of fathers with known occupations be linked systematically to sons with known occupations, representative intergenerational mobility data for strata below that of the elite are exceedingly rare, and selectivity effects are typically severe. In this section, we describe our data, our classification of occupations into strata, the periodization, and we discuss the potential sources of selectivity bias that might be seen to threaten the reliability of the models reported. Given the limitation that our data report only on the mobility of freemen-the top one-third of the urban social structure-we conclude that our sample is representative, that selectivity bias is minimal, and that our mobility models are reliable.

\section{Norwich Freemen}

All of the mobility data used in this article are derived from a register reporting the occupations of the 7,654 men who, from 1548 to 1689 , obtained the freedom of the city of Norwich (Evans 1979; Pound 1966, 1981; Millican 1934). Norwich, England, provides an excellent setting for a study of preindustrial social mobility for a number of reasons. Norwich was the largest and most affluent provincial city in England from 1548 to 1689 ; it was second only to London in social, political, and economic importance. It was a center of the textile industry, the most important sector of the English economy throughout the 16th and 17th centuries. And, most important, the occupational and political structure of 16 th- and 17th-century Norwich has been extensively researched, which provides a framework for inducing the occupational strata that are the focus of this research.

Our analysis is restricted to freemen of Norwich. Men obtained the freedom of the city either through inheritance (patrimony), service (apprenticeship), or purchase ${ }^{3}$ Freedom of the city meant that an individual

fication that results in heterogeneous categories generates unreliable estimates of mobility. Finally, the tendency to import anachronistic categories in our models of preindustrial mobility process, e.g., using a modern classification scheme-professionals, managers, clerical, craftsmen, operative, farmer-where these strata have no tangible salience in historical context, has meant that our understanding of preindustrial mobility is lessened (Hauser 1982).

${ }^{3}$ The distribution of persons who obtained the freedom of the city through inheritance, service, or purchase changed over time. Evans (1979, n. 10) reports that "from 1590 to 1640 the percentage of freedoms gained by patrimony, service, and purchase were $22.7,46.4$, and 30.4 respectively, whereas during the period 1640 to 1690 the percent- 
was a citizen able to engage in commerce, control the labor power of others, and participate in the political life of the community. Men who were not free-that is, men who were not admitted to the freedom of the city-could not engage in a craft specialty, market goods, or take on apprentices or journeymen. Guild and city regulations ruthlessly protected the economic interests of the free citizens by driving out unregistered craftsmen, producers, and commercial agents or forcing these latter to buy freedom to practice their craft.

Consequently, the largest occupational groups in the local economy, the underemployed, agricultural laborers, men with few skills, and journeymen, are not represented. Also not included in the data are the hundreds of women and children who worked in the textile and allied industries as spinners, combers, or carders of wool. Behind the mobility experiences of the stable economic actors lay the majority of Norwich residents who were poor and without prospects. These men and women experienced little mobility and led brutal lives of quiet desperation.

It follows that the mobility models discussed here are restricted to the fortunes of the elite group of economically secure men who were able to obtain the freedom of Norwich. These men compose the strata of "work givers"- the economic actors whose activity drove the local economy throughout the 16 th and 17 th centuries.

Since freedom of the city enabled men to ply their trades, recorders were careful to note the exact occupation for which freedom was obtained. The occupations that were enumerated are extremely detailed. For example, the register notes six different types of weavers, three different grades of masons, and over a dozen types of "textile makers," partitioned by either the type of cloth they worked with or the end product. In all, over 160 distinct occupations were recorded by the listing clerk. One of the benefits of using these lists derives from the detailed occupational data provided. It is clear, though, that detailed cross-classifications

age of freedoms gained by patrimony, service, and purchase were $36.1,50.5$, and 11.7 respectively." Likewise, Pound (1981) reports that, in $1551,17.5 \%$ of new admittances were based on patrimony, rising to "just over 28 percent in the second quarter of the seventeenth century." Despite these shifts, it is important to note that the proportion of sons in our sample who obtained their freedom of the city through patrimony or apprenticeship did not change over time. The real losers in these shifts were strangers who sought to purchase this freedom. Men who purchased freedom were "new men" who were prevented from obtaining their freedom through inheritance or service, and the price of freedom was exceedingly high. In our models these men appear as fathers but not as sons. The increase in the proportion of apprenticeships in period 3 suggests that, despite significant social and political dislocation as a result of the civil war, middle-class men continued to work within the traditional parameters of economic life. Underneath the instability of the political world lay economic stability. 
would yield too many empty cells and that therefore some aggregation of occupations into internally consistent, ranked strata is necessary.

All of the men are middle class, and thus occupy a similar position with respect to the gentry and the mass of the laboring poor. Within the Norwich middle class, occupational groups showed distinctive status and wealth differences that were stable over time (Allen 1951; Pound 1966; Corfield 1976; Evans 1979; Blomefield 1806; Earle 1989). We derive ordered strata from a number of different sources that evidence wealth and status differences across occupations. ${ }^{4}$ We identify seven occupational strata: merchant elite, distributors, skilled craftsmen, weavers, allied cloth workers, leather workers, and semiskilled craftsmen. Below we briefly describe each stratum.

Grocers, mercers, drapers, clothiers, hosiers, and merchants composed the merchant elite of Norwich throughout the 16th and 17th centuries. The merchant elite held substantial property in the city and county and were involved in large-scale translocal commercial markets (Pound 1966; Evans 1979; Fisher 1935; Grassby 1970).

The second stratum, distributors, was composed of a class of purveyors of restricted goods-haberdashers, mongers, brewers, and bakerswhose involvement in the economy was strictly local. The distributive stratum engaged in retail trade (Earle 1989; Crossley 1972).

The third stratum are the skilled craftsmen-goldsmiths, silversmiths, clockmakers, coopers, and wrights - who produced goods for the local luxury market (Earle 1989). Across all strata, these occupational groups were the most successful in ensuring occupational closure through apprenticeship (Millican 1934).

Weavers of bay, silk, russel, dornix, and worsted compose the fourth and intermediate stratum. The typical weaver worked in a small shop with two or three others, controlling very little more than a few looms and a small city lot (Kerridge 1985; Cooper 1969).

\footnotetext{
${ }^{4}$ Some indication of status, net of wealth, for Norwich freemen is the order in which occupations marched in celebratory or political events (Blomefield 1806; Allen 1951). Likewise, the proportion of men from an occupation who are elected as mayor or alderman of the city yields a measure of occupational status (Blomefield 1806; Owens 1970; Allen 1951; Evans 1979). Finally, data on average start-up costs for both merchants and craftsmen -in London - are available and allow us to estimate occupational closure, which we treat as a proxy for occupational status. Together with our understanding of the historical context, these sources provide the framework from which we induce a rank ordering of occupational status. We prefer this use of historical sources to derive the order of strata, rather than an a priori statistical ordering from association models or network models (Breiger 1980), because of the large number of distinct occupations listed in the Norwich register. It is important to note, however, the Sobel et al. (1985) parameterization of quasi symmetry does not depend on ordered categories of the mobility table.
} 
Occupations involved in the production of cloth preparatory to its being woven compose the allied cloth sector. This stratum, as with the weavers, was dependent on textile production for jobs. Composed of dyers, carders, combers, hot pressers, calanders, and sheermen, allied cloth workers engaged in tedious manual labor. These crafts were among the first to be deskilled during the Industrial Revolution (Earle 1989).

Below the allied cloth workers were leather workers, men who manipulated animal skins-tanners, glovers, and hatters. ${ }^{5}$ While constituting $10 \%$ of the free population in Norwich, leatherworkers were considered to be of low status (Evans 1979).

Below all others in the middle class, were the unskilled and semiskilled laborers-carters, porters, carriers, paviors, and fishermen. Despite their relative poverty, compared to the other strata, it is important to recall that they were among the top one-third of the Norwich population whose fortunes, if small, were secured by restricted occupational access and a corresponding diminution of competition from those below.

\section{Sample Selectivity}

A recurrent problem in historical mobility analyses is that the available data are not representative of a population. Our data are derived from freemen's lists and our models are necessarily restricted to the urban social structure and cannot be generalized to mobility processes throughout England. While generally considered to be reliable sources (Pound 1981; Sharlin 1979), freemen's lists have been criticized for misrepresenting occupational distributions following visitations of plague, which yield strata-unique death rates, for idiosyncratic recording of fathers' occupations, and for censoring bias resulting from the differential migration of sons (Dobson 1973; Patten 1977; Woodward 1970). There is no evidence that these concerns affect our results.

While mortality from plague in the textile and weaving sectors was high in $1578-79,1588,1593,1603,1634-35$, and 1666-67, plague deaths were not associated with unusually high admissions to the freedom of Norwich (Evans 1979). Even though in 1578-79 plague resulted in the

\footnotetext{
${ }^{5}$ In the London context, glovers and hatters were high-status occupations, but in Norwich they were considered to be of low status. Of the 589 richest men in Norwich in 1645 , none were leather workers. Over the 140 years under study, no men in the leather trades were elected to elite political positions in the city. Leather work is often associated with impurity and consequently is, even in Western society, considered to be a low-status profession. The Norwich data suggest this was true in urban areas where leather work was not an important industrial activity (Clarkson 1960).
} 
death of one-third of the male population, only $2 \%$ of the new admissions in textiles during the 1580 s appear to have been related to the plague (Pound 1981).

For $18.1 \%$ of the 7,654 men who obtained the freedom of the city from 1548 to 1689 , the recorder for the city listed the occupations of their fathers. These 1,382 father-son pairs make up our study sample. There appears to be no identifiable selection bias from idiosyncratic recording of fathers' occupations. Each occupation within each period had roughly the same proportion of men whose fathers' occupations were listed, and persistence (or the rate of occupational inheritance) rates in these data are similar to those in other urban preindustrial contexts (Sharlin 1979). Neither the characteristics of sons, nor the number of new entrants in a year, played a role in the decision to record a father's occupation; the distribution of occupations for which we have linked father-son pairs is similar to the underlying population.

From the freemen's lists, we have identified 243 pairs of brothers and found that their rates of occupational strata inheritance are almost identical: approximately $66 \%$ of elder sons inherit their fathers' strata while over $61 \%$ of their younger brothers do the same (Bearman, Deane, and McKenna 1991). ${ }^{6}$ While many men migrated from Norwich during this period there is no evidence that the younger sons of Norwich freemen were more likely to migrate than their older brothers. As Thirsk argues (1984, p. 337), "The careers of younger sons and the fortunes of their families call for further investigation at all class levels. . . Primogeniture did not occupy a tyranny over classes below that of the gentry." These data suggest that there is no serious censoring bias stemming from the migration of younger sons.

Considering all of the objections to the use of registers of freemen for studies of occupational structure, Pound (1981, pp. 58-59) concludes that, "While recognizing the importance of wills and inventories as occupational sources where freemen's lists do not exist, and their importance in illustrating those occupations which cannot be obtained from such lists, it is suggested that they are a distinctly inferior, and indeed misleading source. ... As an indicator of primary occupation, freemen's lists are indispensable." Our consideration of selectivity biases supports this general conclusion, and we extend it to include the use of freemen's lists for mobility studies.

\footnotetext{
${ }^{6}$ The $2 \times 2$ cross-classification of elder and younger brothers by strata inheritance and strata mobility yields a $\chi^{2}=0.8,1 d f$. Therefore, we accept the null hypothesis of no difference between brothers.
} 


\section{The Study Sample}

We compare mobility regimes over time, utilizing data on the mobility experiences of 1,382 men over 140 years. The majority of sons (58.9\%) held positions in their fathers' strata. Given these data constraints, our models focus on comparative mobility across periods, which summarizes the moves of two cohorts of freemen-roughly 50 years. Generationspecific models and comparison of mobility regimes across six generations would have been preferable, but the relatively small number of movers meant that, at best, if we assumed a random distribution of destinations from origin, we would have an average of only three sons for each offdiagonal cell of the $7 \times 7$ table. Given this, our strategy has been to partition time in order to yield periods that embrace the most important social and political changes that occurred in England during the period $1548-1689$.

We identify three periods, which appear from the national historical evidence, to present relatively crisp contrasts. The first period (1548-89) was marked by social and political stability; the second period (15901639) witnessed faction formation and increasing political discontent; the third period (1640-89) embraced remarkable political upheaval in civil war, the execution of a reigning monarch, radical parliamentary rule, and a counterrevolution that resulted in the restoration of the Stuart monarchy, which in 1688 broke down in crisis. Internally, all three periods were demographically and economically homogeneous; thus our temporal divisions isolate the association between economic regimes and political action. In the first period, national population growth and available positions grew rapidly. From 1590 to 1639 , population growth continued but the expansion of elite positions constricted-leading to conflict in the English civil war. The third period was defined by marked demographic stagnation (Wrigley 1987, pp. 218-23; Goldstone 1986).

Table 1 summarizes the characteristics of our study sample described above. The top half of table 1 reports the total number of newly admitted Norwich freemen, the number whose fathers' occupations were listed (our study sample), the ratio of admitted freemen to our estimated free populations, and the proportion of admitted freemen in our study sample for each time period. Although our sample proportion declines over the three periods, we find no reason to suspect that our sample is biased. ${ }^{7}$

\footnotetext{
${ }^{7}$ Although we find no evidence of systematic bias in the recording of fathers' occupations across each period, table 1 does show a decline in the proportion of recorded fathers' occupations, from $30 \%$ in period 1 to $23 \%$ in period 2 to $10 \%$ in period 3 . Clerks wrote a short inscription when a freeman was first registered as having freedom of the city. Although they were required only to list the occupation in which freedom was obtained, clerks often embellished the entry with additional personal detail about the freeman. To some, fathers' occupation was of interest, to others, different detailed
} 
TABLE 1

Total and Sampled Freemen and Odds Ratios for the Association between SAMPLED AND LISTED FREEMEN

\begin{tabular}{|c|c|c|c|}
\hline & $\begin{array}{c}\text { Period } 1 \\
(1548-89)\end{array}$ & $\begin{array}{c}\text { Period } 2 \\
(1590-1639)\end{array}$ & $\begin{array}{l}\text { Period } 3 \\
(1640-89)\end{array}$ \\
\hline No. of admissions to freedom ......... & 1,223 & 2,821 & 3,610 \\
\hline $\begin{array}{l}\text { Admissions to freedom/free } \\
\text { population* } \ldots \ldots \ldots \ldots \ldots \ldots \ldots \ldots \ldots\end{array}$ & .52 & .49 & .50 \\
\hline No. in sample ........................ & 369 & 643 & 370 \\
\hline Sample/freeman..$\ldots \ldots \ldots \ldots \ldots \ldots \ldots \ldots$ & .30 & .23 & .10 \\
\hline \multicolumn{4}{|l|}{ Strata } \\
\hline Merchant elite $\ldots \ldots \ldots \ldots \ldots \ldots \ldots \ldots$ & .96 & .88 & 2.00 \\
\hline Distributor .......................... & .96 & .96 & .88 \\
\hline Skilled craftsman...$\ldots \ldots \ldots \ldots \ldots \ldots$ & .99 & 1.14 & 1.28 \\
\hline Weaver $\ldots \ldots \ldots \ldots \ldots \ldots \ldots \ldots \ldots \ldots \ldots \ldots$ & 1.46 & 1.23 & .79 \\
\hline Allied cloth worker $\ldots \ldots \ldots \ldots \ldots \ldots$ & .73 & .74 & .97 \\
\hline Leather worker $\ldots \ldots \ldots \ldots \ldots \ldots \ldots \ldots$ & .93 & .88 & .78 \\
\hline Semiskilled craftsman...$\ldots \ldots \ldots \ldots$ & 1.03 & 1.06 & 1.07 \\
\hline
\end{tabular}

SoURCE. - Millican (1934).

NoTE. - The ratio of admissions to freedom to estimated free population for period 1 is based on counts from the 1580-89 decade only.

* Free population is estimated in the Appendix, table A1.

Table 1 also shows that the proportion of the free population represented by new admissions was constant across the three periods $(.52$ in period $1, .49$ in period 2 , and .50 in period 3 ) and the odds ratios for the association between sampled freemen and listed freemen, shown in the bottom half of table 1, are generally close to "1." There are several exceptions. Allied cloth workers in the first and second periods are underrepresented, while weavers in the first period and the merchant elite in the third period are overrepresented.

The influx, starting in 1565, of Protestant refugees, who brought the new draperies from the Low Countries to Norwich, accounts for the overrepresentation of the weaver stratum in the first period. ${ }^{8}$ Recorders were sensitive to the wave of refugees and distinguished them from na-

information about the freeman was more noteworthy. A careful reading of entries reveals that busy clerks recorded less detail, thus as the number of applications for freedom increased, recorded fathers' occupations decreased, but this proportional decrease over time is not systematically related to fathers' occupational distribution.

${ }^{8}$ In 1565 , letters patent from Queen Elizabeth granted Norwich the power to admit Protestant refugees to the freedom of the city so they could exercise "the faculties of making bays, arras, sayes, tapestry, mockadoes, staments, carsay and such other outlandish commodities as hath not bene used to be made within this our Realme of England" (Millican 1934, p. xiii). 
tives by noting patrimony, even if the new freeman was admitted through apprenticeship.

Overrepresentation of the merchant elite in the third period is likely a by-product of political instability. In a context where the political careers of those in the elite strata were made, unmade, and made again within decades (e.g., there were purges of officeholders in 1648-49, 1660-64, and 1676-88), the lineages of men who controlled significant economic resources would be salient to recorders and others controlling new admissions.

Our sample also underrepresents allied cloth workers in the first and second periods. Other than the possibility that recorders were unable to clearly distinguish allied cloth workers from weavers and thus classified some of them incorrectly, we are unable to account for the underrepresentation of this stratum.

It is interesting that the first period is characterized by pronounced structurally driven upward mobility, despite the fact that it may contain too many lower-status weavers. Likewise, the odds of sons becoming merchant elite in the third period are exceedingly small, even though our sample may overrepresent this category. In both cases the potential bias cuts across the general pattern of mobility. Thus there are no theoretical reasons to expect that it is associated with the dependent variable: the structure of mobility over time. In summary, all the available evidence suggests that our data, our classification of occupations into strata, and our periodization, despite political heterogeneity in the third period, are quite robust given a basic constraint of matching fathers to sons over 140 years three centuries ago.

\section{METHOD AND MODELS}

Father-son occupational strata mobility is measured by using selected log-linear models. We begin by fitting the distributions of each of the three periods, 1548-89, 1590-1639, and 1640-89, independently; we than assess differences in intergenerational strata mobility across time. If sons showed no pattern of intergenerational mobility other than inheriting their fathers' occupational strata, this situation is described by a model of quasi independence. Quasi independence (QI) fits the main diagonal of the mobility table perfectly while positing that stratum of origin and stratum of destination are independent elsewhere in the table and, as such, represents an appropriate baseline for our study. The basis for our analysis, however, is the Sobel et al. (1985) parameterization of the quasi-symmetry model (QS) and its extension for multiway mobility tables (Sobel 1988). Sobel et al. have shown that an acceptable fit of QS allows an unambiguous decomposition of mobility into its structural and 
exchange components, and, as such, QS represents a dramatic advance in our ability to interpret the mobility process.

The concepts of structural and exchange mobility have been important features of studies of intergenerational mobility, but their unambiguous measurement has always been troublesome, and disagreement over the most appropriate analytic approach has been extensive (Cobalti 1988; DiPrete 1990; Hauser 1986; Hauser and Grusky 1988a, 1988b; Hout 1988; Jones 1985a, 1985b, 1986; Krauze and Slomczynski 1986a, 1986b; Slomczynski and Krauze 1988; Sobel 1983; Sobel, Hout, and Duncan 1986). The debate has revolved around the use of log-linear modeling with cell-specific parameter estimates versus more elegant single parameter measures and the decomposition of mobility into structural and exchange components. While we certainly are sympathetic toward simple statements of mobility, we are more concerned with isolating and quantifying the mobility experiences of particular strata in preindustrial Norwich and relating these experiences across time. Cross-classification tables with a one-to-one correspondence among categories, and particularly the QS model, allow us to do this. Following the work of Sobel et al. (1985) we match the concept of structural mobility (mobility caused by transformations in occupational opportunities), with a column effect that accounts for all marginal heterogeneity, and we match exchange mobility with symmetric exchanges between pairs of occupational strata.

When marginal distributions in a square table differ, as is the case with our data, some movement from origin to destination is forced by the unequal marginals. This shift is due to differences in proportional distributions of origins and destinations. Table 2 reports the observed frequencies for our three periods. Data for period 1 in table 2 make it clear that some sons destined for the merchant elite had to come from lower strata, since there were 70 merchant elite fathers and 81 merchant elite sons. In this period, 11 sons would be pulled into the first column. If the movement to a particular destination is allowed to affect all origins proportionately, the movement from origin to destination due to marginal differences represents the concept of structural mobility (Featherman and Hauser 1978; Sobel et al. 1985).

Sobel (1983) and Sobel et al. (1985) have shown that efforts to model structural mobility as the residual of total mobility after the exchange component has been estimated, or conversely, efforts to model exchange as the residual of structural mobility, lack substantive meaning; numerous attempts merely to equate structural mobility with trends in the distributions of occupations over time should also be rejected because many exogenous factors are known to affect origin and destination distributions (Cobalti 1988; Hauser and Grusky 1988a). Under QS, structural mobility may be interpreted as a factor that raises or lowers the odds on 


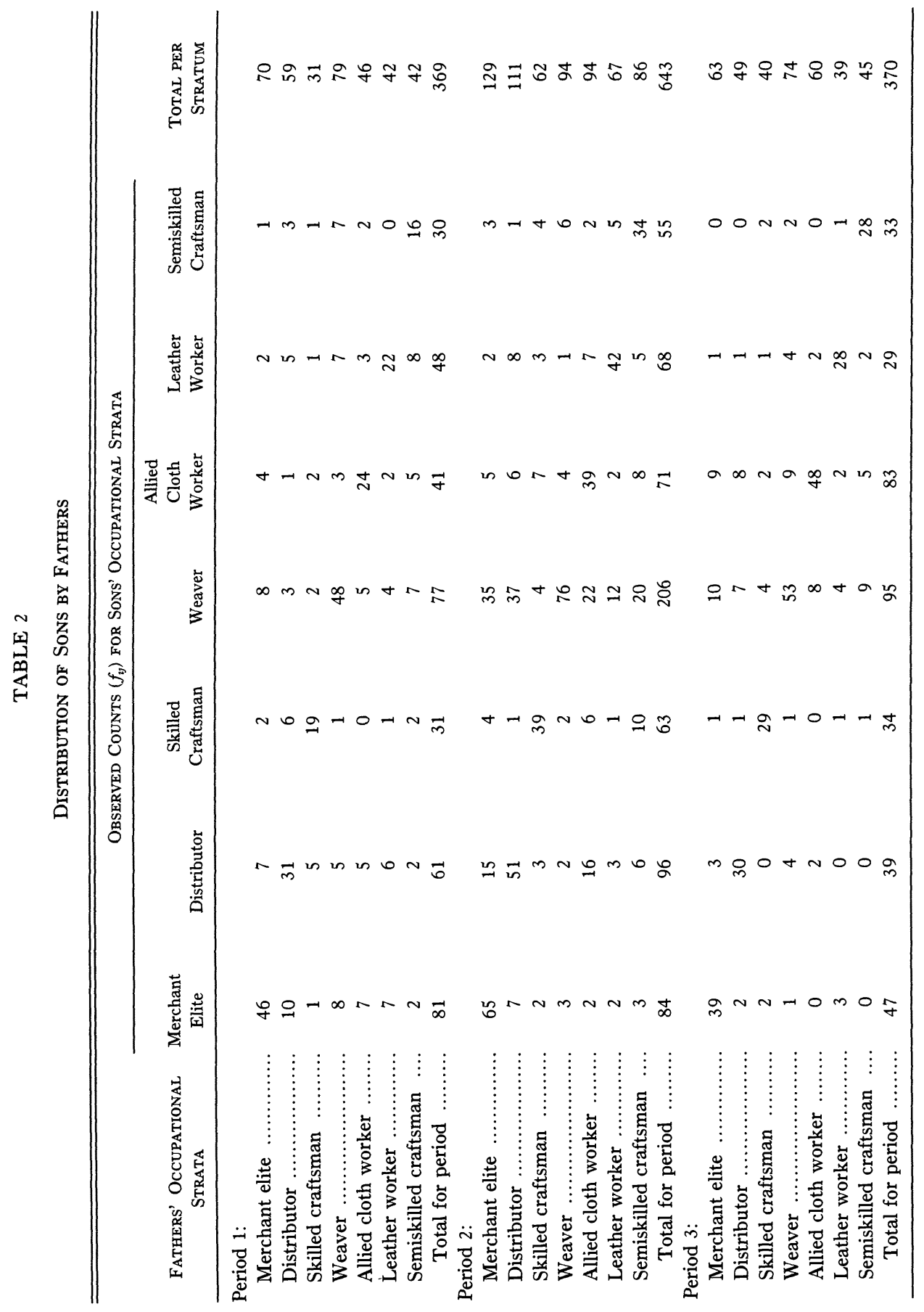


a son's occupational stratum relative to that stratum's proportion of the distribution of fathers' strata (Sobel et al. 1985, p. 361).

On the other hand, the concept of exchange, or circulation, mobility represents the flow between pairs of origins and destinations. Following the QS parameterization, exchange mobility is defined as the equal flow between cells $(i, j)$ and $(j, i)$. The QS model constrains the origindestination interactions to be symmetrical, allowing the marginals to be heterogenous (see also Hout 1983; Knoke and Burke 1980). Exchange coefficients may be interpreted as the odds on sons changing occupational strata relative to staying in their fathers' strata. These parameters measure association inversely to the usual convention for cross-product ratios, that is, a small value indicates a strong association between pairs of strata and, consequently, relatively little exchange.

Model fits are estimated using GLIM (Baker and Nelder 1978). Note that the figures for period 3 in table 2 include a fairly large number of sampling zeroes among those frequencies. Depending on the location of the zeroes in a contingency table, GLIM may produce erroneous parameter estimates with greatly inflated standard errors (SEs). Lindsey (1989) shows that the solution to this problem is to eliminate those zero cells responsible for this occurrence. We utilize this correction when it is appropriate. $^{9}$

Quasi independence, reported in table 3, shows an acceptable fit only for the period from 1640-89, indicating independence of sons' occupational destinations from fathers' occupations for those sons who experienced occupational mobility during this third period. It is during period 3 that we also find a substantial increase in the proportion of observed frequencies along the main diagonal of the mobility table. From 1548 to 1639 , that is, periods 1 and 2, approximately $55 \%$ of all sons inherited their father's occupational stratum. This figure jumps to nearly $70 \%$ during period 3.

Quasi symmetry fits father-son strata mobility in all three periods, particularly well in period $1\left(\chi^{2}=16.02,15 d f\right)$ and period $3\left(\chi^{2}=\right.$ $13.17,13 d f)$. Although QS fits the observed frequencies in period 2 under a conventional definition of statistical significance, we can substantially improve the model fit by including an apparent asymmetric exchange between the weaver and semiskilled craftsmen strata. The additional $\gamma$ parameter reduces the $\chi^{2}$ of QS by 5.79 with the loss of $1 d f .^{10}$ This

\footnotetext{
${ }^{9}$ When sampling zeroes affect a fitted model, some residuals of observed minus fitted cell frequencies will be either very large positive or negative. In these cases, a zero weight is assigned to the offending cell, while all other cells are weighted by their frequencies (Lindsey 1989).

${ }^{10}$ Under QS, expected cell frequencies are the product of three types of parameters: alpha $\left(\alpha_{j}\right)$ coefficients, which capture marginal shifts between fathers' strata and sons'
} 
TABLE 3

Selected Models for Father-Son Occupational Mobility

\begin{tabular}{|c|c|c|c|}
\hline & $\chi^{2}$ & $d f$ & $P$ \\
\hline \multicolumn{4}{|l|}{ Period 1, 1548-89: } \\
\hline QI model ...................... & 41.53 & 29 & .03 \\
\hline QS model ..................... & 16.02 & 15 & .20 \\
\hline \multicolumn{4}{|l|}{ Period 2, 1590-1639: } \\
\hline QI model ................... & 64.14 & 29 & .00 \\
\hline QS model .................. & 25.24 & 15 & .05 \\
\hline $\mathrm{QS}+\gamma$ model $^{*} \ldots \ldots \ldots \ldots$ & 19.45 & 14 & .18 \\
\hline \multicolumn{4}{|l|}{ Period 3, 1640-89: } \\
\hline QI model ........... & 30.51 & 29 & .23 \\
\hline QS model ................... & 13.17 & 13 & .28 \\
\hline \multicolumn{4}{|l|}{ Across all periods, $1548-1689$ : } \\
\hline CQS model ..................... & 54.45 & 43 & .05 \\
\hline $\mathrm{CQS}+\mathrm{H}_{\alpha}$ model $\ldots \ldots \ldots$ & 112.40 & 55 & .00 \\
\hline $\mathrm{CQS}+\mathrm{H}_{\delta}$ model $\ldots \ldots \ldots$ & 129.00 & 83 & .00 \\
\hline
\end{tabular}

$* \gamma_{t j}=\gamma$ when $i=4$ and $j=7, \gamma_{t}=1 / \gamma$ when $i=7$ and $j=4 ; \gamma_{t j}=1$ otherwise.

unreciprocated exchange between sons of semiskilled craftsmen who moved upward into weaving occupations and sons of weavers who eschewed semiskilled occupations warrants caution when interpreting the structural and exchange mobility ratios formed by these two strata (Sobel et al. 1985, 1986). Note also that the change in $\chi^{2}$ from QI and QS also is statistically significant for periods 1 and 2 , but not for period 3 ( $\Delta \chi^{2}$ $=25.51,14 d f, \Delta \chi^{2}=38.90,14 d f$, and $\Delta \chi^{2}=17.34,16 d f$, for periods 1,2 , and 3, respectively). ${ }^{11}$ Although QI fits the period 3 cross-classification quite well, a further test of the difference between the model of symmetry and QS (not shown) is statistically significant, thus establishing the contribution of structural mobility. It follows that we have no compelling reason to examine its parameter estimates more closely.

Since our purpose is also to offer insight into the extent of the change in occupational strata mobility over 140 years, we now combine the

strata; delta $\left(\delta_{i j}\right)$ coefficients, which measure the association between symmetric pairs of occupational strata; and beta $\left(\beta_{j}\right)$ coefficients, which represent symmetric adjustments for fathers' and sons' marginal frequencies. In addition, where QS does not strictly hold, some degree of unreciprocated mobility between pairs of strata is operating. This asymmetrical association and/or uniform effect may be denoted as gamma $\left(\gamma_{i j}\right)$ (Sobel et al. 1985; Sobel et al. 1986).

${ }^{11}$ Note that the difference in degrees of freedom for the QS model between period 3 and periods 1 and 2 is due to the correction for sampling zeroes. This reduction in degrees of freedom is due to the elimination of two parameter estimates with grossly inflated SEs. Thus the correction establishes a more stringent test of the QS model fit in the presence of sampling zeroes. 
period-specific QS models into a three-way contingency table, a conditional quasi-symmetry model (CQS) of fathers' strata with sons' strata by period (see Sobel 1988). Under CQS, interactions with period are of substantial interest because they quantify the shifts in structural and exchange mobility across the study periods and allow explicit tests of the period heterogeneity assumption.

Given the acceptable fit of CQS (shown in "Across all periods," table 3 ), we next try imposing homogeneity restrictions for period on structural and exchange mobility parameters. The first alternative model posits that CQS holds but that there is no difference in structural mobility over the three periods (CQS $+H_{\alpha}$ ); the second alternative tests whether exchange mobility across the three periods is homogeneous (CQS $+H_{\delta}$ ). Since neither of these restrictions on the CQS model attain an acceptable fit, and the change in $\chi^{2}$ from CQS to CQS $+\mathrm{H}_{\alpha}$ and from CQS to CQS $+\mathrm{H}_{\delta}$ are statistically significant $\left(\Delta \chi^{2}=57.95,12 d f\right.$, and $\Delta \chi^{2}=$ $74.55,40 d f$, respectively), we conclude that no general statements about structural and exchange mobility may be made about the three periods.

In summary, the strata mobility models reported in table 3 have shown that (1) each period is adequately described by QS, (2) the values of parameters that estimate structural and exchange components of strata mobility are unique within each period, and (3) period 3 is best fit by the model of QI. Although the conclusion that the occupational destinations of sons who do not inherit their fathers' stratum is independent of fathers is succinct and conceptually simple, the presence of structural mobility is not precluded by an acceptable fit of QI. Consequently, we make specific inferences about strata mobility from the QS (tables 4-6) and CQS (table 7) parameter estimates.

\section{RESULTS}

Period 1: 1548-89

In the period from 1548 to 1589 , sons benefited from almost uniform upward structural mobility which drew them into the more elite destinations. Structural mobility ratios between categories are reported below the diagonal in rows $11-16$ in table 4 . These ratios index the extent of downward or upward social mobility as driven by structural changes exogenous to exchange mobility. Ratios less than one mean that structural mobility was downward, ratios greater than one imply upward mobility as the result of marginal shifts. In interpreting these ratios, we give particular attention to values above 1.3 and below 0.7 , which we consider to be of substantive significance.

We are interested in sons' opportunities relative to fathers as they are conditioned by structural change. Consider the odds of a son becoming 


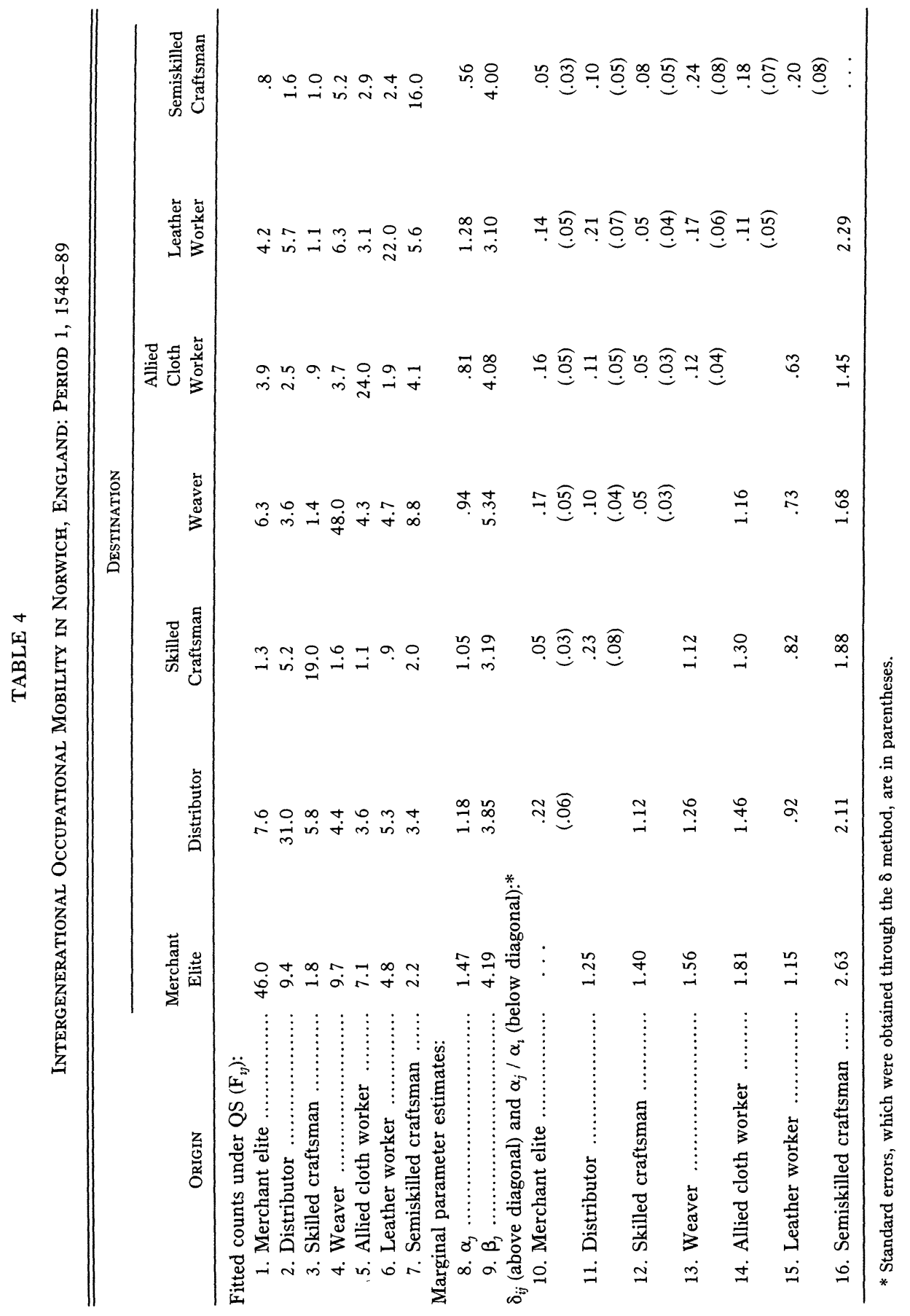


a merchant relative to the odds of a merchant's son losing status and becoming a retailer, craftsman, weaver, or semiskilled craftsman. These odds are reported, for each category, down the first column. Thus, for instance, the son of a semiskilled craftsman is 2.63 times more likely to become a merchant than a merchant elite's son is to become a semiskilled craftsman. Independent of origin, all sons have greater opportunity to move into the merchant elite than the merchant elite sons have of moving down. In period 1, from above, sons can expect to do better than fathers by virtue of pervasive upward structural mobility. Sons of the merchant elite remain in the elite, although the openness of the category yields dilution of the elite status.

These mobility ratios evidence, with the exception of the leather workers category, a monotonic ordering down the columns of the lower half of table 4. The expansion in higher-status strata during this period creates an excess of positions for sons of lower-status fathers; consequently, the ratio for sons of distributors becoming merchant elites is lower than that for merchant sons whose fathers were semiskilled craftsmen. Demonstration of the strength of upward structural mobility above the dyadic level, where structural effects for occupation pairs are revealed, is induced from the ordered pattern of the $\alpha_{j}$ coefficients (see row 8, table 4). Disrupting this monotonic pattern is the case of the leather trades. The leather industry expanded somewhat throughout the late 16th century (Clarkson 1960) and consequently almost all sons, independent of origin, were drawn into the industry. Note that $\alpha_{j}$ for leather workers is 1.28 , which demonstrates an excess of sons of various origins entering the leather trade. Note that while ratios for the leather workers (across row 15 , table 4) are almost all less than one, only the ratio for sons of allied cloth workers reaches substantive significance (.63).

As QS fits these data we are able to uniquely partition the mobility process into its constituent components: mobility as a result of marginal shifts (structural mobility) and mobility as a result of exchange (circulation or exchange mobility). Above the diagonal in rows 10-16 of table 4, we report the $\delta_{i j}$ coefficients for each pair of strata. Small coefficients report strong association and indicate little exchange that can be attributed to association, while large coefficients report weak association and signal substantial exchange; if an association coefficient is insignificant then the exchange between a particular pair of origin and destination is essentially open (Sobel et al. 1985).

Note that in period 1 every $\delta_{i j}$, except for the stratum of skilled craftsmen, is small and statistically significant, suggesting strong association. Apparently, occupational strata were closed to strata encroachment, even from those strata closely arrayed in social space. In general, mobility in the period 1548-89 is described by a patterned movement of sons upward 
through the urban occupational strata, despite the globally strong association between origins and destinations.

Period 2: $1590-1640$

In the 50 years preceding the English civil war of 1640, the fortunes of the Norwich middle class worsened. In this period, downward structural mobility was profound, and it forced sons of elites into lower-status positions.

Consider table 5, row 8, which reports $\alpha_{j}$ coefficients for period 2 . Recall that values less than one index downward mobility. Structural change in this period is driven by the expansion of the weaver occupational stratum and the simultaneous severe contraction of all other occupations. Thus, less than half as many sons as expected (.47) became merchant elites, and while more than five times the expected proportion of sons became weavers, the upward mobility of weavers' sons was almost completely eliminated. This pattern can be more clearly demonstrated if we turn to the mobility ratios for estimating structural mobility as reported in rows $10-16$ of table 5 .

Reading down column 1, we see that the odds of a distributor becoming a merchant elite are half (.48) that of a merchant elite becoming a distributor. Considered from the point of view of an elite son, this means that sons of elites are twice as likely to move down to distributors than sons of distributors are to move up. Sons of elites experience downward mobility, and sons of retailers have blocked aspirations as the result of occupational closure. With one exception (row 12, col. 2), which does not appear substantively significant, each of the three top occupation groups experience downward mobility relative to the adjacent category.

While the elite occupations are closed to those below, much of the action is occurring with the weavers as reported in column 4 (to obtain ratios for downward mobility for the top three occupations into the weaver category, compute the inverse of row 13). The odds of any son becoming a weaver are 4-11 times greater than the odds of a weaver's son moving to another occupation. Weaving occupations drew men down and up the mobility ladder. This observation becomes even more striking when we consider the mobility ratios representing the odds on upward mobility for the sons of weaver fathers. Sons of weavers had practically no opportunity for structurally driven upward mobility, as their odds on moving up are all less than 0.2 . Related to the expansion of opportunity in weaving, however, the sons of allied cloth workers and semiskilled workers experienced a degree of upward mobility, although, again, they were blocked from the merchant elite, and the bulk of their opportunity for advancement was to be found in the weaving occupations. 


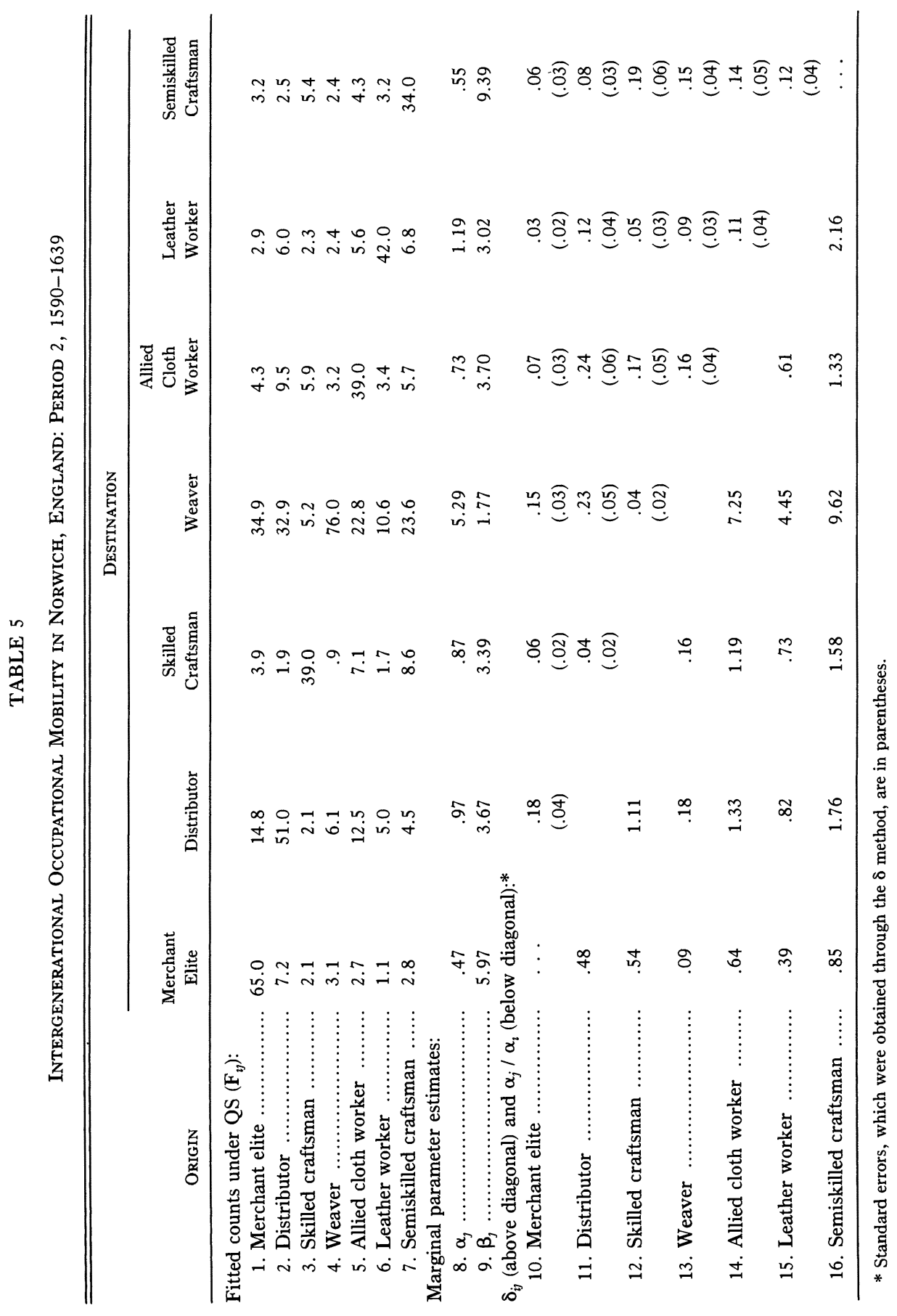


Consider now the association between pairs of occupational strata (rows 10-15 above the diagonal in table 5). Almost all of the $\delta_{i j}$ coefficients are small, indicating strong association and statistical significance. As in period 1, there is no pattern to the associations based on occupational distance. Although exchange mobility continued to be an important component of occupational mobility, mobility-up or down-was defined by economic crisis and the structure of opportunity.

\section{Period 3: 1640-89}

The pattern of downward structural mobility evidenced in the years preceding the English civil war continued during the period 1640-89 for sons of the merchant elite, distributors, and textile workers (see table 6). On the other hand, sons of skilled craftsmen and leather workers were forced up into near and adjacent occupational categories, while sons of semiskilled workers continued to gain throughout the urban occupational structure.

While marginal shifts tended to drive sons' mobility in the third period, association between origins and destinations remained extremely strong across strata. Coincident with these observations, however, we note that, relative to the mobility experiences across other periods, the proportion of movers over stayers was very low. As mentioned in the previous section, almost $70 \%$ of sons during this period inherited the occupational strata of their fathers, and the distribution of sons relative to fathers fits the QI model quite well. The odds of a son inheriting his father's occupational stratum tell the compelling economic history of this period.

The stratum of weaving occupations, containing the largest number of fathers, absorbed its sons at a rate of almost four times that for mobile sons; this was by far the weakest persistence found in Norwich during period 3. Sons of skilled craftsmen were almost 65 times more likely to become skilled craftsmen than to take occupations outside this stratum. In between these extremes, sons of the merchant elite, of distributors, of allied cloth workers, of leather workers, and of semiskilled craftsmen were all at least 10 times more likely to work within their fathers' strata than to have become economically mobile.

\section{Mobility Over Time: Period Effects}

The mobility of sons relative to their fathers' occupational strata has been our focus so far. We have found substantial differences in structural mobility across periods. Here we consider structural and exchange shifts across periods. Table 7 reports period-specific comparisons of the components of structural mobility. 


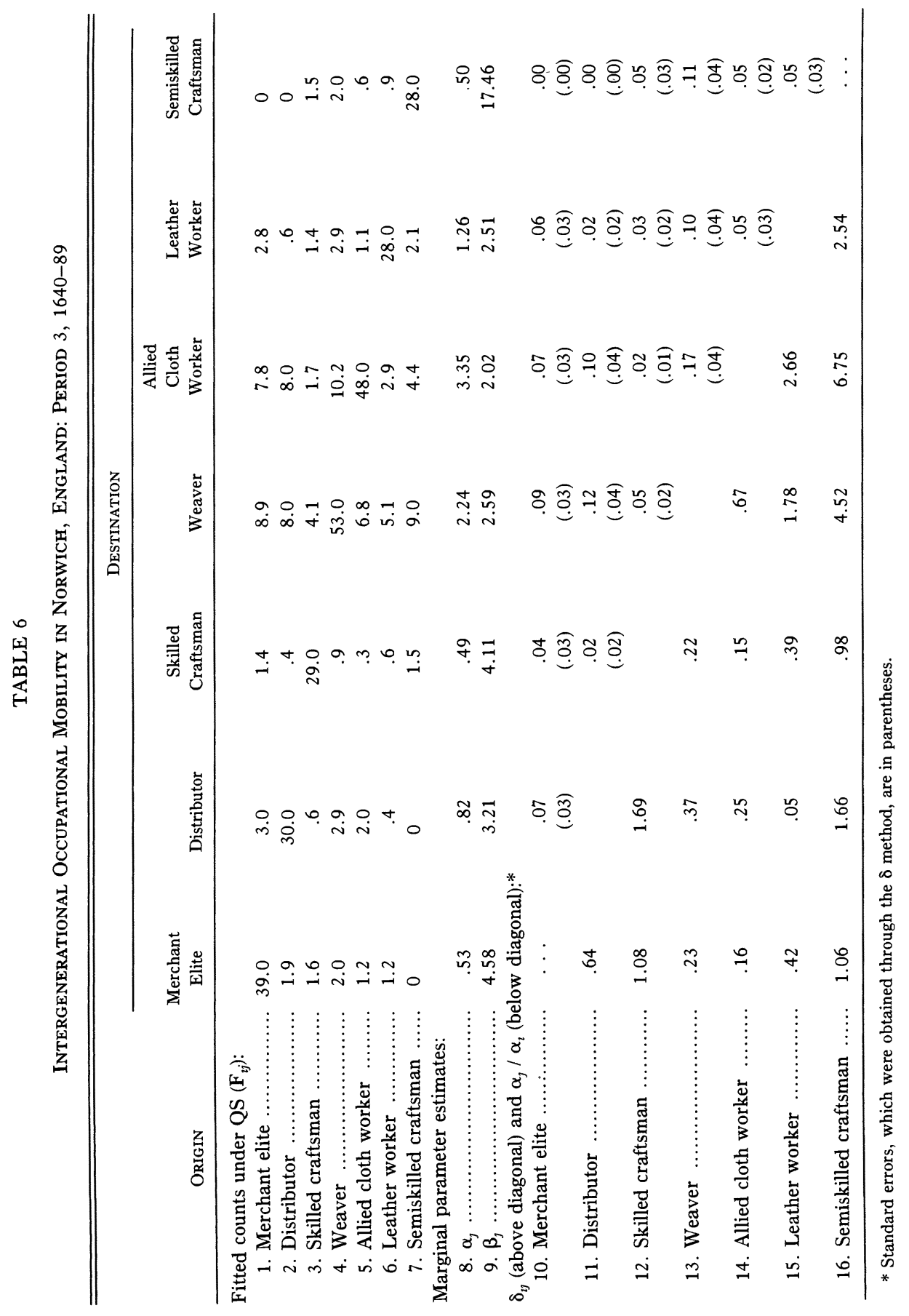




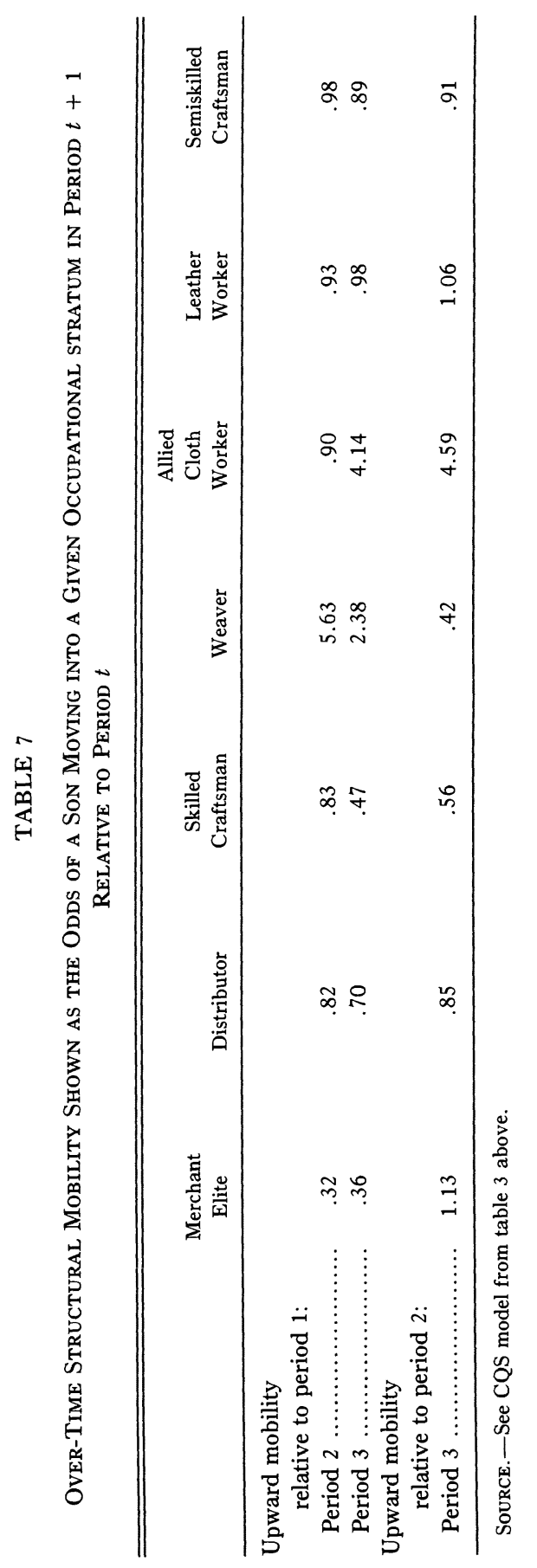


Column 1 reports the odds of sons becoming merchants in period $t$ +1 relative to period $t$, column 2 the odds of becoming a distributor in period $t+1$ relative to period $t$, and so forth. As shown earlier, the alpha parameters yield odds ratios that represent an excess or deficit in the expected proportion of sons in particular occupational strata. In light of this, table 7 reveals the collapse of opportunity in the elite occupational strata (merchants, distributors, and skilled craftsmen), temporal stability of strata at the bottom of the Norwich occupational order, and the growth and contraction of structural opportunity in Norwich's core strata: the weavers and allied cloth workers. Mobility into weaving occupations explodes in the beginning of the 17 th century then declines relative to this second-period peak, while expansion of opportunity in the allied cloth sector begins in the middle of the 17 th century. Relative to the 16 th century, opportunity in the elite strata was closed. Sons in periods 2 and 3 were only one-third as likely as first-period sons to join the merchant elite stratum $(.32, .36)$, and the odds of sons in lower strata becoming distributors or skilled craftsmen were not much better. Finally, we see almost no temporal change in structural opportunity among the leather workers and semiskilled craftsmen for periods 2 and 3 relative to period 1 , and for period 3 relative to period 2 .

Contrary to the action shown by the temporal measures of structural mobility, measures of exchange (not shown) report a high degree of constancy over time. Although the model that postulates a homogeneity of exchange over time (the CQS $+\mathrm{H}_{\delta}$ model in table 3 above) does not provide an adequate fit, comparisons of period 2 and period 3 with period 1 , and period 3 with period 2 reveal only three statistically significant differences among exchange parameters in each of the comparisons with period 1 and only one difference between periods 2 and $3 .{ }^{12}$ We can now say that the rigidity of strata barriers to exchange persisted across the 140 years preceding England's Industrial Revolution.

\section{DISCUSSION}

Recall the crucial cultural, political, economic and structural changes that occurred in English society from 1548 to 1689: the radical civil war, which permanently altered the structure of politics; the rise of Puritanism; the industrialization of the countryside; the emergence of national commodity, food, and labor markets; and the rise of large-scale urban manufacturing. Two classes played a critical role in driving these transitions: the landed elite and the urban middle class. We know less about the

${ }^{12}$ Model program code and full sets of parameter estimates are available on request from the authors. 
middle class than about the elite. This article initiates what we hope will be a new interest in the determinants of urban, commercial, middle-class political action. Our basic theme is that opportunity and the structure of the intergenerational mobility regimes that govern opportunity matter. Our central conclusions are that structural mobility governed opportunity for freemen, that its strength and direction changed over time, and that political action was tied to economic opportunity. Below we identify the structural forces driving mobility over time.

\section{Period 1: The Tudor Ascendancy and Upward Mobility}

From 1548 to 1589 structural shifts served to drive sons into higher positions than their fathers. At the local level, the expansion of the elite strata was governed by two interrelated processes-the emergence of Norwich as a local center for elite consumption, and the development and subsequent expansion of the "new draperies" textile sector (Allen 1951; Evans 1979; Coleman 1969; Kerridge 1985). ${ }^{13}$

The localism of commodity markets, and especially the luxury markets, made possible an elite culture centered in Norwich which induced the expansion of the strata for elite merchants, distributors, and skilled craftsmen. ${ }^{14}$ Elizabethan state policy encouraged thousands of Protestant emigrants seeking to flee religious persecution in the European low countries to establish themselves in England, and it was these men who brought with them the techniques eventually adopted by the Norwich weaving community for producing light woolens (Allen 1951; Allison 1960, 1961). At home, Elizabethan economic policy acted to bolster the fortunes of the sheep farmers and, consequently, to stabilize English wool production levels, despite the fact that with inflationary grain prices and declining wool quality, an investment in crops was often more profitable than an investment in sheep (Bowden 1956, 1967; Wilson 1960). Although both the home and export markets for cloth showed weaknesses throughout the latter half of the 16th century, the new worsted wools continued to be a growth sector for the English economy as a whole (Gould 1971). The Norwich middle class benefited from these national and local developments - the net result being upward structural mobility. During this period Norwich politics were remarkably consensual (Allen

${ }^{13}$ These were light, fashionable worsted fabrics made mostly from inferior English long-staple wool and suited primarily for the export markets in the Mediterranean.

${ }^{14}$ During this period (1548-89) the English landed gentry largely exchanged "feudal" trappings-manors and retainers-for country estates and conspicuous consumption of luxury goods. The shift from the manor to the market as a determinant of elite status drove the expansion of the luxury goods market. 
1951). Political stability is a likely by-product of sustained upward mobility.

\section{Period 2: Instability and Downward Mobility}

In the second period the national economy experienced periods of severe depression (1590-1600, 1620-40) and some strength (1600-20). Deep declines in the textile sector were tempered in Norwich, in part because the end of the war with Spain (1604) opened new markets for the new draperies and also because the worsted wool market was strong in the southern European countries, whose economies were more robust than those of northern Europe (Bowden 1967). If the economy of the second period was unstable, so was the court. By 1590 , the Tudor political position had weakened considerably. The last decades of Elizabeth's reign were marked by fiscal crisis, price inflation, political intrigue, faction formation, and uncertainty - structural conditions that the Stuart monarchs inherited and subsequently deepened in the pre-civil war period.

The mobility experiences of the Norwich middle class in this period reflect national, rather than local, developments. In Norwich, while the textile sector showed strength, the three elite strata declined markedly. Motivating declines in the elite strata were exogenous changes, mainly the breakdown of local luxury markets resulting from the shift toward London as the center for elite status achievement (Stone 1965). Both processes involve the emergence of a national elite world centered on London, which was established during the late Elizabethan and early Stuart periods. As a result of these larger structural changes, sons of elites experienced downward mobility and sons of lower-stratum fathers experienced blocked ambitions.

\section{Period 3: Status Persistence and Political Conflict}

By July 1642, all hopes for peace were gone. For the next three years, England was at war with itself. By August, 2,000 men in Norwich were armed and prepared to defend the city against a potential Royalist attack. In December, the Eastern Association arrested the mayor (a Royalist), and by the end of March 1643 the entire Royalist party in Norwich was crushed (Evans 1979). Whereas other provincial cities became isolated, Norwich politics during the civil war and interregnum were defined by the politics of London and Parliament. In 1645, conflicts between Independents and Presbyterians spilled out from London and organized the bases for conflict in Norwich. Independents in Norwich, and elsewhere, achieved power over Presbyterians, but at a cost. In Norwich, the failure of a Presbyterian coup in 1648 left 200 men dead and led to the purge of 
all conservative leaders from local offices. By 1649, Independents controlled the city scene, but for the next decade, until the dismissal of the Protectorate, factional strife in Norwich was intense. By 1659, the political elite of the city ruled without, and often against, the popular will.

Even before General Monck arrived in London, 794 citizens of Norwich signed a petition presented to the Rump Parliament which demanded a restored bull Parliament. Popular and elite discontent were marked. A majority of the citizens and the magistracy supported the king's return in 1660, and while waiting for guidance from Monck before acting, were poised to reconstruct the local political scene. In the period from 1660 to 1663 , the Commonwealth leaders were purged and a fragile association of restored Royalists and conservative Presbyterians controlled the city. In 1664 this alliance broke down and political conflicts again simmered to the surface. For the next 25 years, these conflicts, defined at the national level, structured local Norwich politics (Evans 1979).

The conflicts, and the parties which gave them meaning, Whig and Tory, Presbyterian and Independent, were over ideal ends and not tangible economic or social reform. Unlike London, where Levellers and other groups were powerful enough to mark political thought, Norwich political conflicts were not driven from below. Nor were they driven by economic processes occurring within the city-the marked decline of markets in textiles and luxury goods. When the political context appears autonomous, we do not expect to find an association between the mobility experiences of men and political outcomes.

But this was not the case in the English civil war of 1640. The leading actors in the interregnum were men who obtained their freedom in 1620-25. We seek to account for their actions on the basis of their mobility experiences as young men. Many of the leading figures were merchant elites, as is shown in table 8. Members of this and other strata experienced blocked mobility in their youth. But the new radicals disproportionately came from strata whose mobility fortunes were constrained by structural processes beyond their control. These men, living in parishes dominated by weavers and allied cloth workers, were collectively radicalized and took active roles in the revolutionary movements of the time (Evans 1979). While data on the political persuasions of most freemen are not available, we note that freemen from the strata most constrained by the mobility regime were more likely to become officeholders during the interregnum than at any other time.

Of the restoration and political battles of the late half of our period we can say less with certainty. The men who played the leading roles after 1664 obtained their freedom of Norwich in the early years of the civil war period. Most men were stayers, and those who moved were as likely 
TABLE 8

Odds Ratios for the Association between Stratum and Holding Political OFFICE IN NORWICH, 1620-89

\begin{tabular}{|c|c|c|c|}
\hline Strata & $\begin{array}{c}\text { Pre-Civil War } \\
\text { Period, } \\
1620-39\end{array}$ & $\begin{array}{c}\text { Revolutionary } \\
\text { Period, } \\
1640-59\end{array}$ & $\begin{array}{c}\text { Restoration } \\
\text { Period, } \\
1660-89\end{array}$ \\
\hline Merchant elite $\ldots . . . \ldots \ldots \ldots \ldots$ & 2.7 & 2.1 & 2.5 \\
\hline Distributor $\ldots \ldots \ldots \ldots \ldots \ldots \ldots \ldots$ & 1.6 & 1.5 & 2.0 \\
\hline Skilled craftsman $\ldots . \ldots \ldots \ldots \ldots$ & .0 & .3 & .4 \\
\hline Weaver $\ldots \ldots \ldots \ldots \ldots \ldots \ldots \ldots \ldots$ & .6 & 1.8 & .9 \\
\hline Allied cloth worker $\ldots \ldots \ldots \ldots \ldots$ & .2 & 1.4 & .4 \\
\hline Leather worker..$\ldots \ldots \ldots \ldots \ldots$ & .0 & .0 & .0 \\
\hline Semiskilled craftsman $\ldots \ldots \ldots \ldots$ & .0 & .0 & .2 \\
\hline
\end{tabular}

SoURCE.-Evans (1979).

to go up as they were to go down (see table 6). The political conflicts of this period were swift and intense. We believe that in the absence of clear and powerful mobility processes, which drive the fortunes of entire strata in a consistent manner, politics will be driven by springs independent of the underlying economic and social processes for which mobility models provide one trace. While it appears counterintuitive to link occupational persistence to intense political conflict, we note that politics are often a focus of human activity precisely when the ends that govern actions are decoupled from underlying economic and social processes.

\section{Radicalization}

Beyond analysis of the structure of middle-class opportunity in England from 1548 to 1689 , we note two significant implications, the first of which is historical while the second is methodological. A major historical concern is understanding the political outcomes following periods of structurally driven downward occupational mobility. In this case, the consequences of downward mobility in the pre-civil war period (1590-1639) suggest a process of radicalization that led middle-class men in strata experiencing the greatest downward and blocked mobility to disproportionately support Parliament. In the civil war Norwich went for Parliament, but not uniformly and not without struggle between elite factions competing for control of the city's political and administrative offices. Despite evidence of political conflict, which at times led to the mobilization of the whole city, Evans (1979) argues that the revolutionary leaders of Norwich were drawn from the same strata as the traditional elite. Our 
analysis of his data does not support this conclusion. Rather, we show that radical urban leaders were disproportionately likely to occupy positions in occupational strata below the Norwich social elite.

Following Evans (1979), we define as the political elite men holding office in Norwich. By estimating the odds ratios for the association between stratum and political office we can usefully compare the distribution of officeholders by strata over time. ${ }^{15}$ We define the revolutionary period as the years from 1640 to 1659 , the pre-civil war period as the years from 1620 to 1639 and the restoration period as the years from 1660 to 1689 . We report, in table 8 , the odds on becoming an officeholder in each period.

Across all three periods, the merchant elite and distributors' strata were more likely to be represented among the political elite than would be expected from chance, but their contribution decreased during the interregnum. In the revolutionary period, weavers and allied cloth workers were as likely as men in the top two strata to hold office. At no other time were men from strata other than that of the distributors or merchant elite likely to hold political office in Norwich. Note also that the structural mobility ratios for the weaver and allied cloth sectors (reported in rows 13 and 14 of table 5) are generally less than one, indicating a net inflow of sons whose fathers were from higher occupational strata. This collective experience underlay the radicalization of these strata as evidenced by their disproportionate support for Parliament during the civil war. Our disaggregation of the middle class yields occupational strata that experienced differential opportunity; beginning in 1640, these strata differences appear to have played a critical role in structuring radical urban politics during the English civil war.

We identify the political radicalization of strata within an urban middle class as a consequence of sustained, structurally driven downward mobility in the 50 years preceding the English civil war, and we necessarily wonder whether this association holds across context. Radicalization and revolutionary activity, in a context of sharp economic decline following periods of general expansion, is not an uncommon historical experience (Davies 1962; Goldstone 1982, 1991). Our findings suggest a similar pat-

${ }^{15}$ The odds ratios are formed as the ratio of two ratios; the number of political officeholders from each stratum over the total number of officeholders, and the number of freemen per stratum (Evans 1979) over the total number of freemen in the given interval (Millican 1934). We approximate the number of freemen during the 1620-39 interval by counting sons in the Norwich register from 1548-89, the number of freemen in 1640-59 by counting fathers in the register from 1590-1639, and the number of freemen in the 1660-89 interval by counting sons in the register during the 15901639 period. The odds on being an officer, reported in table 8, are thus standardized by strata counts. 
tern, but one organized over a long period. Since mobility is perceived as individual attainment, only when structural processes completely govern a mobility regime for sustained periods of time will individuals interpret opportunity as socially organized. When this occurs, we expect an association between a mobility regime and politics. It follows that other instances of popular radicalization may be associated with structurally driven downward mobility. We note that the middle class has consistently played an important role in major historical revolutions (Davies 1963; Moore 1966; Skocpol 1979). Perhaps more important than the structure of interclass transfer are temporal shifts in the opportunity structure within the middle class that induce radical action.

\section{Implications}

In this article we show that a partition of the structural and exchange components of English middle-class mobility regimes from 1548 to 1689 yields insight into political and economic processes not otherwise observed. From 1548 to 1589 , middle-class men were propelled into higherlevel occupations than their fathers as the result of structural processes that generated elite vacancies. It is not surprising to find that collective prosperity is associated with political stability. From 1589 to 1639, structural processes reversed themselves, and, for two generations, sons faced obstacles to upward mobility. Most sons fared worse than their fathers. The cohort of men facing blocked aspirations were those who, in 1640, participated in a violent civil war. Men from strata experiencing blocked mobility were more likely during the revolutionary period than an an time before or after to become leaders in Norwich. We associate downward mobility with radicalization of this cohort and argue that there is an elective affinity between mobility experiences of men and subsequent political action.

The equation of mobility processes and political outcomes is not uniform nor does it necessarily hold in all periods. Politics of elites pursuing ideal ends in a context defined by the absence of structural mobility processes-as in period 3-are not expected to be driven by a mobility regime. Only where one finds consistently strong structural processes organized over a lengthy period of time can one expect an association between a mobility model and political outcomes.

\section{APPENDIX}

Estimation of Free Population in Norwich, 1548-1689

The number of freemen in Norwich at any given time can be approximated from the number of new admissions before that time. Evans (1979) 
sets the average age of becoming a freeman in our period 2 at just over 27 years; he sets that figure at 25.5 years for our period 3 . If we assume a life expectancy of 56 years for the first group and 52.5 years for the second group (Wrigley 1968; Laslett 1965), the free population can be estimated by surviving forward new admissions from appropriate model life tables (Coale and Demeny 1983).

Our method employed five-year survival probabilities from the West model life table levels 3 (before 1640) and 5 (after 1640) for males. These tables provided the closest match to additional expectation of life (29 years for those who obtained freedom of the city before 1640 and 27 years for those who became freemen after 1640) for newly admitted freemen. The method does require a stable population assumption, but we feel the procedure produces acceptable estimates. Essentially, we "survive" forward the cohorts of admitted freemen from six earlier decades (say, cohorts from times $t$-1 to $t$-6) using the survival probabilities from the model life tables to yield a free population at time $t$. Thus the estimated free population at 1680 , for instance, is generated from the 886 entries from $1670-79 \times .91 \times .89$ (the survival probabilities from ages $25-29$ and 30-34 West model life table for males level 3) +886 entries from $1660-69 \times .91 \times .89 \times .87 \times .85$ (survival probabilities ages $25-29$, $30-34,35-39,40-44)+642$ entries from $1650-59 \times .91 \times .89 \times .87$ $\times .85 \times .82 \times .79+620$ entries from $1640-49 \times .91 \times .89 \times .87 \times$ $.85 \times .82 \times .79 \times .73 \times .66+654$ entries from $1630-39 \times .92 \times$ $.91 \times .89 \times .87 \times .85 \times .81 \times .77 \times .69 \times .61 \times .49$ (the survival probabilities from ages $25-29, \ldots$, $70-74$ West model life table for

TABLE A1

Admissions to Freedom and Estimated Free Populations in Norwich

\begin{tabular}{lccc}
\hline \hline Years & $\begin{array}{c}\text { Admissions } \\
\text { to Freedom }\end{array}$ & $\begin{array}{c}\text { Total Free } \\
\text { Population }\end{array}$ & Ratio \\
\hline $1580-89$ & 502 & 974 & .52 \\
$1590-99$ & 434 & 1,059 & .41 \\
$1600-09$ & 456 & 1,049 & .43 \\
$1610-19$ & 630 & 1,039 & .61 \\
$1620-29$ & 672 & 1,175 & .57 \\
$1630-39$ & 654 & 1,317 & .50 \\
$1640-49$ & 620 & 1,407 & .44 \\
$1650-59$ & 642 & 1,407 & .46 \\
$1660-69$ & 886 & 1,386 & .64 \\
$1670-79$ & 886 & 1,544 & .57 \\
$1680-89$ & 559 & 1,657 & .34 \\
\hline
\end{tabular}

SourCes. - Evans (1979); Coale and Demeny (1983). 
males level 5) +672 entries from $1620-29 \times .92 \times .91 \times .89 \times .87$ $\times .85 \times .81 \times .77 \times .69 \times .61 \times .49 \times .33 \times .22$.

Table A1 reports the number of admissions to freedom and the estimated number of freemen by decade from 1580 to 1689 , using available counts of admissions from the Norwich register (Millican 1934; Evans 1979). Note that while new admissions report fluctuations between decades caused by economic and epidemiological conditions, the ratio of admissions to free population at any given time was near .50, with the notable exception being the decade 1680-89 during which the ratio falls to .34. The premature admission of over 300 men for political reasons following the Restoration-note the jump to 886 new admissions between 1660-69 and 1670-79-accounts for this unusual decline (Evans 1979).

\section{REFERENCES}

Allen, Bruce Halliday. 1951. The Administrative and Social Structure of the Norwich Merchant Class. Ph.D. dissertation. Harvard University, Department of History.

$\rightarrow$ Allison, K. J. 1960. "The Norfolk Worsted Industry in the Sixteenth and Seventeenth Centuries." Yorkshire Bulletin of Economic and Social Research 12:73-83.

$\rightarrow \rightarrow$. 1961. "Wool Supply and the Worsted Cloth Industry." Yorkshire Bulletin of Economic and Social Research 13:61-77.

Baker, R. J., and N. A. Nelder. 1978. The GLIM System, Release 3. Oxford: Numerical Algorithms Group.

Bearman, Peter S. 1992. Relations into Rhetorics. ASA Rose Monograph Series. New Brunswick, N.J.: Rutgers University Press (in press).

Bearman, Peter S., Glenn Deane, and Michael McKenna. 1991. "Birth Order and Status Persistence: Occupational Mobility in England, 1548-1640." Working paper. University of North Carolina at Chapel Hill, Department of Sociology.

Blomefield, Francis. 1806. History of Norfolk. Vols. 1-11. London.

Bowden, P. J. 1956. "Wool Supply and the Woolen Industry." Economic History Review, 2d ser., 9:44-58.

- 1967. "Agricultural Prices, Farm Profits, and Rents." Pp. 593-695 in The Agrarian History of England and Wales, IV, 1500-1640, edited by Joan Thirsk. Cambridge: Cambridge University Press.

Breiger, Ronald L. 1981. "The Social Class Structure of Occupational Mobility." American Journal of Sociology 87:578-611.

Clarke, Peter, ed. 1976. The Early Modern Town. New York: Longman.

Clarkson, L. A. 1960. "The Organization of the English Leather Industry in the Late Sixteenth and Seventeenth Centuries." Economic History Review, 2d ser., 13:245-57.

Coale, Ansley J., and Paul Demeny. 1983. Regional Model Life Tables and Stable Populations, 2d ed. New York: Academic Press.

$\rightarrow$ Cobalti, Antonio. 1988. "Alternative Conceptual Frameworks for the Analysis of Mobility Tables and the Log-Linear Models." Quality and Quantity 22:31-47.

Coleman, D. C. 1969. "An Innovation and Its Diffusion: 'The New Draperies.' " Economic History Review, 2d ser., 22:417-29.

Cooper, J. P. 1969. "Economic Regulation and the Cloth Industry in Seventeenth Century England." Transactions of the Royal Historical Society, 5th ser., 20:73-99. 


\section{American Journal of Sociology}

Corfield, P. 1976. "A Provincial Capital in the Late Seventeenth Century: The Case of Norwich." Pp. 90-112 in The Early Modern Town, edited by Peter Clarke. New York: Longman.

Crossley, D. W. 1972. "The Performance of the Glass Industry in Sixteenth-Century England." Economic History Review, 2d ser., 25:421-33.

Davies, James C. 1962. "Toward a Theory of Revolution." American Sociological Review 27:5-19.

- 1963. Human Nature in Politics: The Dynamics of Political Behavior. New York: Wiley.

DiPrete, Thomas A. 1990. "Adding Covariates to Loglinear Models for the Study of Social Mobility." American Sociological Review 55:757-73.

Dobson, R. B. 1973. "Admissions to the Freedom of the City of York in the Later Middle Ages." Economic History Review, 2d ser., 26:1-22.

Earle, Peter. 1989. The Making of the English Middle Class. Berkeley: University of California Press.

Evans, John T. 1979. Seventeenth-Century Norwich: Politics, Religion, and Government, 1620-1690. London: Clarendon.

Everitt, Alan. 1969. The Local Community and the Great Rebellion. London: Historical Association.

Featherman, David L., and Robert M. Hauser. 1978. Opportunity and Change. New York: Academic Press.

Fisher, F. J. 1935. "The Development of the London Food Market." Economic History Review 5:95-117.

Goldstone, Jack A. 1982. "The Comparative and Historical Study of Revolutions." Annual Review of Sociology 8:187-207.

- 1986. "The Demographic Revolution in England: A Reexamination." Population Studies 49:5-33.

1991. Revolution and Rebellion in the Early Modern World. Berkeley: University of California Press.

Gould, J. D. 1971 . "Cloth Exports, 1600-1640." Economic History Review, 2d ser., 24:249-57.

Grassby, Richard. 1970. "The Personal Wealth of the Business Community in Seventeenth-Century England." Economic History Review, 2d ser., 23:220-34.

Guest, Avery M., Nancy S. Landale, and James C. McCann. 1989. "Intergenerational Occupational Mobility in the Late 19th Century United States." Social Forces 68:351-78.

$\rightarrow$ Hauser, Robert M. 1982. "Occupational Status in the Nineteenth and Twentieth Centuries." Historical Methods 15:111-26.

. 1986. "Reinventing the Oxcart: Jones' Obsolete Proposal for Mobility Analysis." Social Forces 64:1057-65.

Hauser, Robert M., and David B. Grusky. 1988a. "Cross-National Variation in Occupational Distributions, Relative Mobility Chances, and Intergenerational Shifts in Occupational Distributions." American Sociological Review 53:723-41.

-1988b. "Errors in Slomczynski and Krauze's Comparative Analysis of Mobility." American Sociological Review 53:749-52.

Hexter, J. H. 1963. Reappraisals in History: New Views on History and Society in Early Modern Europe. Chicago: University of Chicago Press.

Hout, Michael. 1983. Mobility Tables. Beverly Hills, Calif.: Sage.

- 1988. "More Universalism, Less Structural Mobility: The American Occupational Structure in the 1980s." American Journal of Sociology 93:1358-1400.

Howell, Roger. 1967. Newcastle-upon-Tyne and the Puritan Revolution. Oxford: Oxford University Press.

Jones, F. L. 1985a. "New and (Very) Old Mobility Ratios: Is There Life after Benini?" Social Forces 63:838-50. 
$\longrightarrow \rightarrow-.1985 b$. "Structural and Circulation Mobility are Alive and Well: A Critical Comment of Sobel's Premature Obituary Notice." Sociology 19:139-42.

- 1986. "Response to Hauser." Social Forces 64:1066-72.

Katz, Michael. 1975. The People of Hamilton, Canada West: Family and Class in a Mid-Nineteenth Century City. Cambridge, Mass.: Harvard University Press.

Kerridge, Eric. 1985. Textile Manufactures in Early Modern England. Manchester: Manchester University Press.

Knoke, David, and Peter J. Burke. 1980. Log-Linear Models. Beverly Hills, Calif.: Sage.

$\rightarrow$ Krauze, Tadeusz K., and Kazimierz M. Slomczynski. 1986a. "Matrix Representation of Structural and Circulation Mobility." Sociological Methods and Research $14: 247-70$

$\rightarrow \rightarrow$. 1986b. "Structural and Circulation Mobility in the Linear Programming Framework: The Critics in Hot Water-a Rejoinder to the Invited Comment 'Saving the Bath Water.'" Sociological Methods and Research 14:247-70.

Kriedte, Peter, Hand Medich, and Jurgen Schlumbohm. 1981. Industrialization before Industrialization: Rural Industry and the Genesis of Capitalism. New York: Cambridge University Press.

Lachmann, Richard. 1987. From Manor to Market: Structural Change in England, 1536-1640. Madison: University of Wisconsin Press.

Landale, Nancy S., and Avery M. Guest. 1990. "Generation, Ethnicity, and Occupational Opportunity in Late 19th Century U.S." American Sociological Review 55:280-96.

Laslett, Peter. 1965. The World We Have Lost: England before the Industrial Age. New York: Scribners.

Lindsey, James K. 1989. The Analysis of Categorical Data Using GLIM. Lecture Notes in Statistics, vol. 56. New York: Springer-Verlag.

Millican, Percy. 1934. The Register of the Freemen of Norwich, 1548-1713. Norwich: Jarrold.

Moore, Barrington, Jr. 1966. Social Origins of Dictatorship and Democracy: Lord and Peasant in the Making of the Modern World. Boston: Beacon.

Owens, Gary L. 1970. "Norfolk, 1620-1641: Local Government and Central Authority in an East Anglian County." Ph.D. dissertation, University of WisconsinMadison, Department of History.

Patten, John. 1977. "Urban Occupations in Pre-industrial England." Transactions of the Institute of British Geographers 2:296-313.

Pound, J. F. 1966. "The Social and Trade Structure of Norwich, 1525-1575." Past and Present 34:49-69.

- 1981. "The Validity of the Freemen's List: Some Norwich Evidence." Economic History Review, 2d ser., 34:48-59.

Skocpol, Theda. 1979. States and Social Revolution. Cambridge: Cambridge University Press.

Sharlin, Allan. 1979. "From the Study of Social Mobility to the Study of Society." American Journal of Sociology 85:338-60.

Slomczynski, Kazimierz M., and Tadeusz K. Krauze. 1988. "A Paradigmatic Crisis in the Multiplicative Modeling of Mobility Tables: The Problem of Circulation Mobility as an Anomaly - an Invited Comment on Hauser and Grusky." American Sociological Review 53:742-48.

Sobel, Michael E. 1983. "Structural Mobility, Circulation Mobility, and the Analysis of Occupational Mobility: A Conceptual Mismatch." American Sociological Review 48:721-27.

. 1988. "Some Models for the Multiway Contingency Table with a One-to-One Correspondence among Categories." Pp. 165-92 in Sociological Methodology 1988, edited by Clifford C. Clogg. Washington, D.C.: American Sociological Association. 


\section{American Journal of Sociology}

Sobel, Michael E., Michael Hout, and Otis Dudley Duncan. 1985. "Exchange, Structure, and Symmetry in Occupational Mobility." American Journal of Sociology 91:359-72.

$\longrightarrow \rightarrow$. 1986. "Saving the Bath-Water: An Invited Comment on Krauze and Slomczynski's 'Matrix Representation of Structural and Circulation Mobility.' " Sociological Methods and Research 14:271-84.

Stone, Lawrence. 1965. The Crisis of the Aristocracy, 1558-1640. Oxford: Clarendon Press.

Thernstrom, Stephan. 1964. Poverty and Progress: Social Mobility in a Nineteenth Century City. Cambridge, Mass.: Harvard University Press.

Thirsk, Joan. 1984. The Rural Economy of the Seventeenth Century. London: Hambledon.

Walzer, Michael. 1965. The Revolution of the Saints: A Study in the Origins of Radical Politics. Cambridge, Mass.: Harvard University Press.

Weber, Max. 1958. The Protestant Ethic and the Spirit of Capitalism. New York: Scribner's.

Wilson, Charles. 1960. "Cloth Production and International Competition in the Seventeenth Century." Economic History Review, 2d ser., 13:209-21.

Woodward, D. M. 1970. "Sources for Urban History: Freemen's Rolls." Local Historian 9:90-91.

$\rightarrow$ Wrigley, E. A. 1968. "Mortality in Pre-industrial England: The Example of Colyton, Devon, over Three Centuries." Daedalus 97:546-80.

1987. People, Cities, and Wealth. Oxford: Basil Blackwell. 